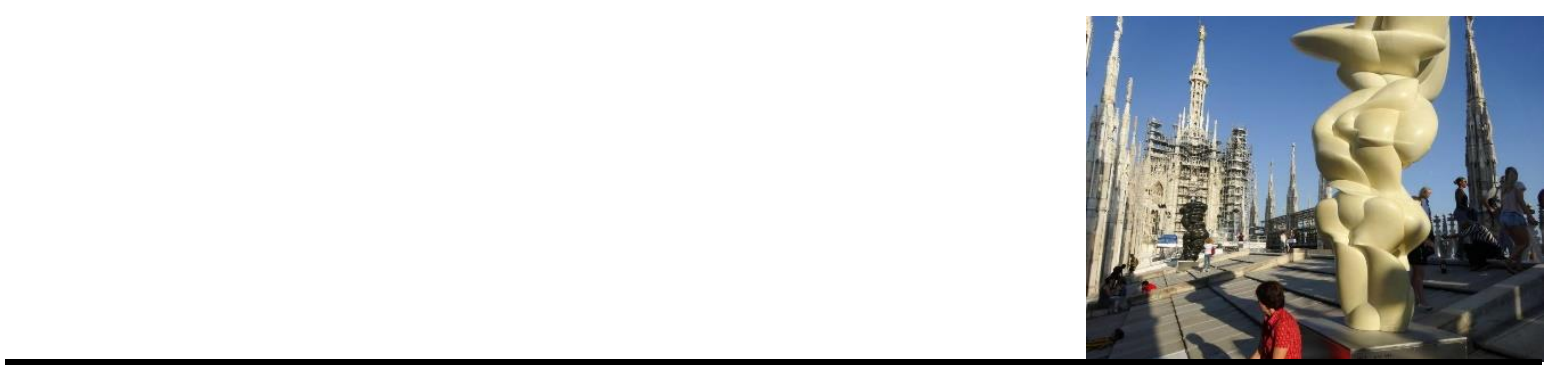

DOI: 10.21005/pif.2021.46.B-02

\title{
THE CITY AS A FREE ART GALLERY. THE RELATIONSHIP BETWEEN THE EXHIBIT AND THE EXHIBITION SPACE
}

\author{
MIASTO GALERIA BEZ BILETU. RELACJA OBIEKT EKSPONOWANIA \\ A PRZESTRZEŃ EKSPOZYCJI
}

\author{
Magdalena Gyurkovich \\ dr hab. \\ Author's Orcid number: 0000-0003-4275-0435 \\ Politechnika Poznańska \\ Wydział Architektury \\ Instytut Architektury i Planowania Przestrzennego
}

\begin{abstract}
The city is an artwork in itself, as its urban and architectural structure creates unique spaces that offer emotions and experiences on various scales. Details and sculptures are used to build the city's nature and recognisability. The paper presents an approach to the city as an exhibition, where the relationship between the environment and the displayed object is created. What is the contemporary role of these works of art, such as sculpture, in urban space? Do they only fill the space or commemorate historical facts, or were they consciously arranged in relationship with their surroundings to create unique values?
\end{abstract}

Key words: displaying, composition, relationship with the background.

\section{STRESZCZENIE}

Miasto samo w sobie jest dziełem sztuki, urbanistyczno-architektoniczna struktura tworzy niepowtarzalne przestrzenie o różnych skalach doznań i emocji. Detale i rzeźby wykorzystuje się do budowy jego charakteru i rozpoznawalności. Artykuł przedstawia spojrzenia na miasto jako zagadnienie wystawiennicze, gdzie budowana jest relacja pomiędzy otoczeniem a obiektem eksponowanym. Jaką rolę odgrywają dziś wspomniane dzieła sztuki, na przykład rzeźby w przestrzeni miasta - czy tylko wypełniają przestrzeń lub są świadectwem historycznych faktów, a może zostały świadomie wkomponowane $w$ relacji z otoczeniem w celu stworzenia unikatowej jakości?

Słowa kluczowe: eksponowanie, kompozycja, relacja z tłem. 


\section{INTRODUCTION}

The conducted research was inspired by the presentation of sculptures by Igor Mitoraj in Poznan in 2003 (Mitoraj, 2003) and in Krakow and Warsaw in 2004 (Badach, 2004, p.71). The works were displayed in the urban space in the Old Market (Stary Rynek) in Poznan, the Market Square (Rynek Główny) in Krakow, and in the front and back courtyards of the Royal Castle in Warsaw. Seventy sculptures were also displayed in exhibition interiors, but it was the public spaces of three polish cities that became, for a while, the main "exhibition halls". The exhibition of one artist at a unique scale, which was arranged in publicly available space amidst everyday life, revealed that markets and squares were interesting and stimulating exhibition environments. The sculptures by Mitoraj perfectly matched the scale and proportions of the place, while the locations added a distinctive historical narration to the presentation (Fig.1, 2, 5, and 12-15). The artist drew inspiration for his works from references to the Ancient and Renaissance periods, which interplayed with the display locations. This artistic event is not unusual. Urban spaces often host presentations of works of art (Fig.3, 4, and 8), performances, theatre events or exhibitions as separate presentation zones in various scales. Rarely is it possible to achieve cohesion between the urban surroundings and the artistic presentation. It is possible more often for the display of single objects or permanent locations.
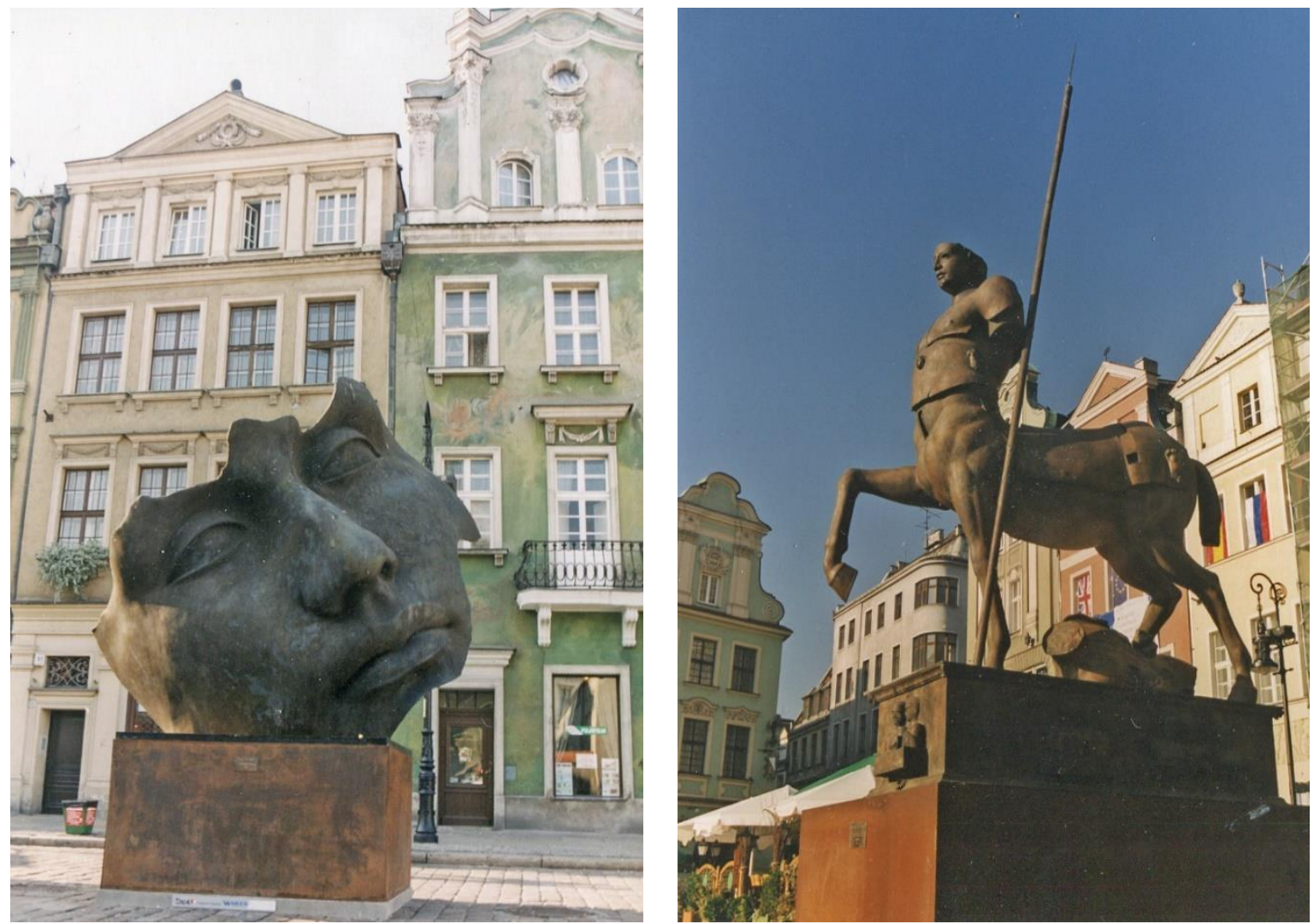

Fig 1, 2 Exhibition of Igor Mitoraj's sculptures, Poznań. Source: Photo: Z. Kosicki 2003

Ryc. 1, 2 Wystawa Mitoraja Poznań. Źródło: fot. Z. Kosicki 2003

The beauty of a city is determined by its layout, the proportions of urban interiors, high quality level of architectural objects and well-arranged greenery (Bardzińska-Bonenberg, T., Sobczyńska, K. 2018 , p. 10), along with transportation solutions and a multitude of other factors. An indispensable factor that affects the perception of a city is also the quality of life of its inhabitants, which includes living conditions, and the sense of comfort and safety. The aesthetical quality of space is equally 
important for its perception. The contact with works of art may improve the values mentioned above. Their roles are varied. Works of art are present around us as:

- architectural works, whose location is strongly linked to the town-planning arrangement,

- sculpture or painting as details of buildings,

- objects with narrative references are those, whose function is to commemorate an event or a person, and their location is strongly connected to the content or prestige of the location,

- works of art (sculptures, murals, urban furniture) provide urban spaces with content, enhancing its artistic values.

The relationship between these types of works of art and the space, in which they are displayed, significantly influences their perception. When describing the actions that result in the emergence of these objects, we use the terms: placement, location, mounting, placing. Why not talk about exhibiting, displaying or presenting instead? It may seem merely a play of words, but in building spatial relations, expression and narrative, they operate on different levels of the design decisions. The city as an exhibition space (with the exclusion of parks and recreation zones ${ }^{1}$ ) and the analogies to interiors of exhibition halls are the topic of this article.

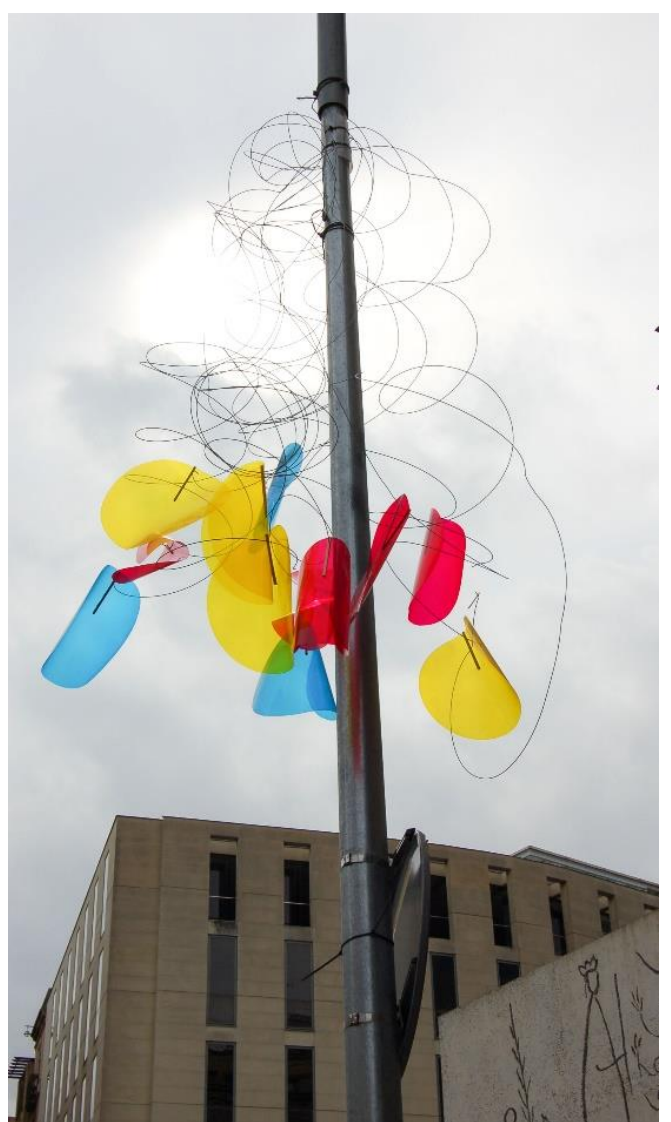

Fig. 3. Installation in urban space - Barcelona. Source: Photo: M. Gyurkovich 2013

Ryc. 3. Instalacja w przestrzeni miasta - Barcelona. Źródło: fot. M. Gyurkovich 2013

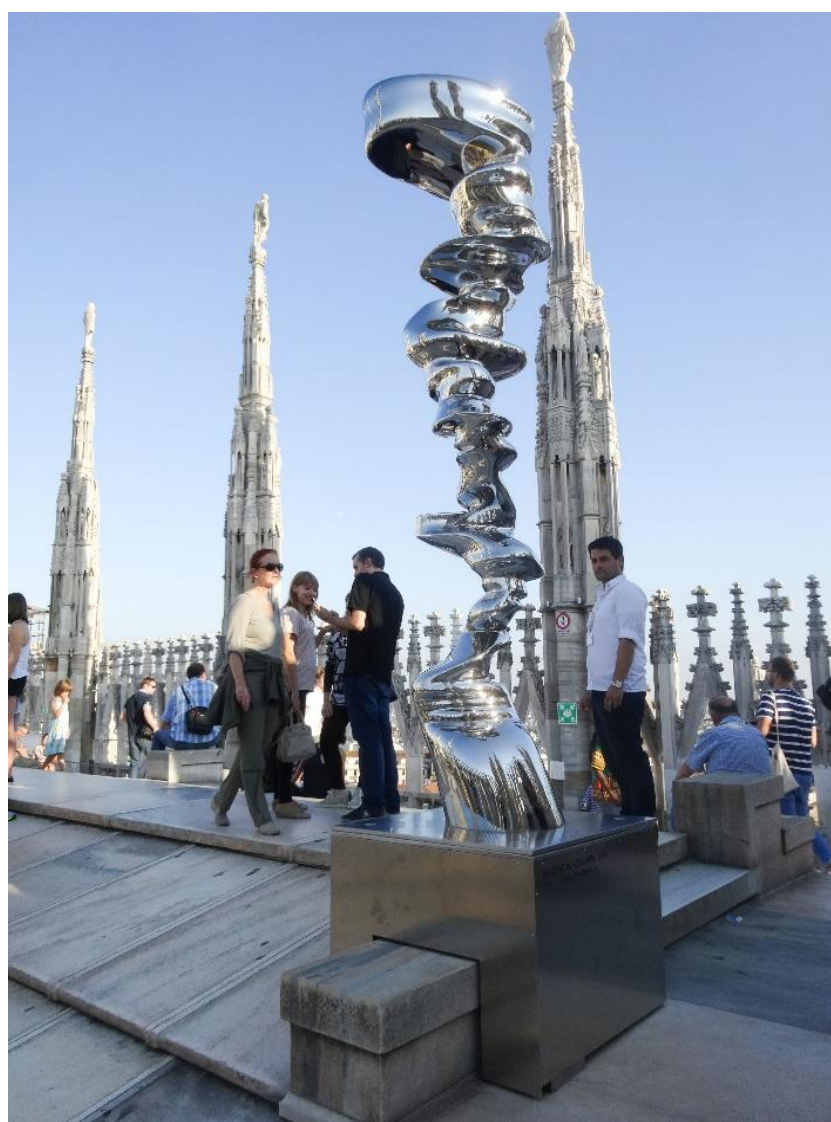

Fig. 4. Sculptures on the roof of the Cathedral in Milan. Source: Photo: M. Gyurkovich 2015

Ryc. 4. Rzeźby na dachu Katedry w Mediolanie. Źródło: fot. M. Gyurkovich 2015

\footnotetext{
1 Artykuł dotyczy relacji obiekt eksponowania a przestrzeń ekspozycji w zwartej części miasta, tereny rekreacyjne i parkowe wymagają oddzielnego opracowania.
} 


\subsection{Methodology}

In research on the relationship between the exhibit and the exhibition space there are certain special cases, when the place and the object are equally important for the perception. Sculptures or murals are embedded in the urban space as elements of composition, of the aesthetic or symbolic narration. The exhibition of Igor Mitoraj is an example of a temporary exhibition that refreshed the interiors of markets and squares. In order to understand whether a city is an art gallery visited by viewers daily free of charge and without any restrictions, mixed research methodology was adopted, including: literature review, observational analysis of individual solutions, comparative analysis, and a case study of the exhibition in Poznan in 2003 and in Warsaw and Krakow in 2004.

\section{AN OBJECT OF ART IN THE CITY. THE NEED}

Cities are people. (Gehl J., 2014, p. 25). Their development so far has resulted in the depopulation of city centres, which is caused by urban sprawl, scattered functions, new functions, means of communication, and many other factors. People gather where something happens, in places that generate positive experiences (Gehl J., 2014, p.77). According to research conducted by Jan Gehl, varied details and attractive equipment of the public space result in increased activity and participation of the inhabitants of such space. Works of art are used to arrange these places, but their emergence does not guarantee success in itself. An uncomfortable bench, on which a sculpture is seated to make sure that anyone will sit there at all (Gehl J., 2014, p. 144), is an example of filling the space rather than displaying.

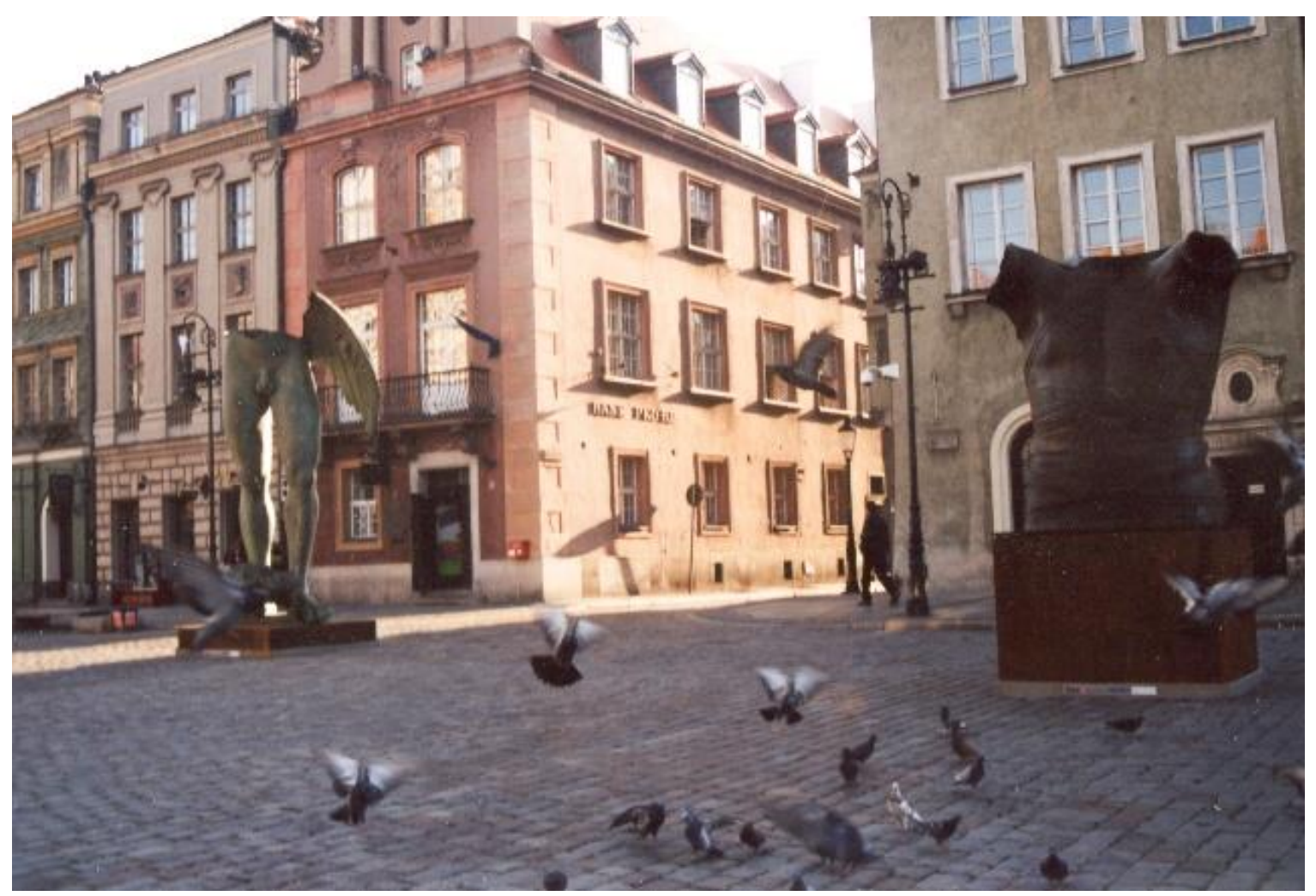

Fig. 5. Exhibition of Igor Mitoraj's sculptures, Poznań. Source: Photo: Z. Kosicki 2003

Ryc. 5. Wystawa Mitoraja Poznań. Źródło: fot. Z. Kosicki 2003 
Public spaces are the location of diverse phenomena, relations and needs. These spaces shape their nature, being a contemporary response to the city's needs. From the point of view of studies on public space, Katarzyna Pluta (Pluta K., 2012, p. 231) distinguished, among others:

- Harmonious relationship between works of art,

- Dominant originality of an architectural object in the public space,

- Architectural objects that provide a background for modern public space solutions, i.e. the new cityscape.

This author referred this dependence to the relationship between the work of art as an architectural object to the public space. Identified relationships are also assigned to works of art other than architecture. Harmony is a specific relationship that improves the quality of a place, highlights its beauty, but also puts an order in the relationship that displays the object and is beneficial for its surroundings. This is one of the main differences between displaying art in urban space in comparison to exhibition halls. In a museum or art gallery the aim is to present the exhibit, while in the public space it is important what happens to the place where the object is presented. Ideally, the object, the place, and the background are displayed at the same time. The exhibition of sculptures by lgor Mitoraj is an example of such harmonious synergy of the location, sculptures, and historical background (Fig.1, 2, 5, and 12).

"Dominant originality" is a relationship that prevents displaying anything on such a background, as well as an overly dominant form, e.g. of a sculpture, may overshadow the background, making it impossible to achieve harmony. The sculpture by Richard Deacon "Between Fiction and Facts" in Vieleneuve-d'Aacq (France) is an example of such dominance (Uffelen Ch., 2012, p. 136). Works of dominant originality, scale, or expression are exhibitions with the spotlight on one "actor", which may bring positive values to the space: a single leading gesture or form may give the place a unique nature, put aside the disharmony of relationship and establish an axis of the composition. Such role is played by numerous monuments, especially those that commemorate historical or political facts, but also the Trevi Fountain (Rome), created by Nicolo Salvi, which took over and dominated the space, giving it a distinctive nature (Uffelen Ch., 2012, p. 44).

Jan Gehl notices the essence of the city's edge - the meeting point of public space and the city and the role of its quality in maintaining the intensity of experiences (Gehl J., 2014, p. 75). The background being the frontages of streets or squares may affect various planes of display. What is attractive in a long compositional axis, the edge of the city or a building, may be monotonous or tiring in close display, and often, due to the requirements of its function - lifeless (e.g. closed windows of grocery stores). This critical moment also becomes an opportunity for interesting interactions between the displayed object and the background. An example of such mutual complementariness in the arrangement of the sculptures "Nierozpoznani" (Unrecognized) by Magdalena Abakanowicz in front of the front façade of the "Baltic" building by MVRDV. The composition of five casts softens the "city edge". One may have the impression that the concept of the arrangement took into account how it will be perceived by pedestrians and those who drive along one of the main streets of Poznan. One of the sculptures is placed very close, so that the object and the background become integrated. It is worth noting that this is a typical transport space, and the selected works of art match this narration and significantly enhance the quality of the location (Fig.6, 7,and 10).

Another important thing is that the cities accelerate, the time of spatial perception is shortened, the roads become wider, and many details tend to blur. Reconciling the pace of the city and the new details that emerge: information boards, signs, and advertisements, is becoming a challenge for shaping the way of displaying objects. This aspect was emphasised in the studies of Anna JanuchtaSzostak:

Considering the uniformization of cultural patterns, objects of visual arts in public spaces take over a very responsible role - the crystallisation of the cognitive map of the city and creating the identity of the place (Januchta-Szostak A. 2207, p. 53). 

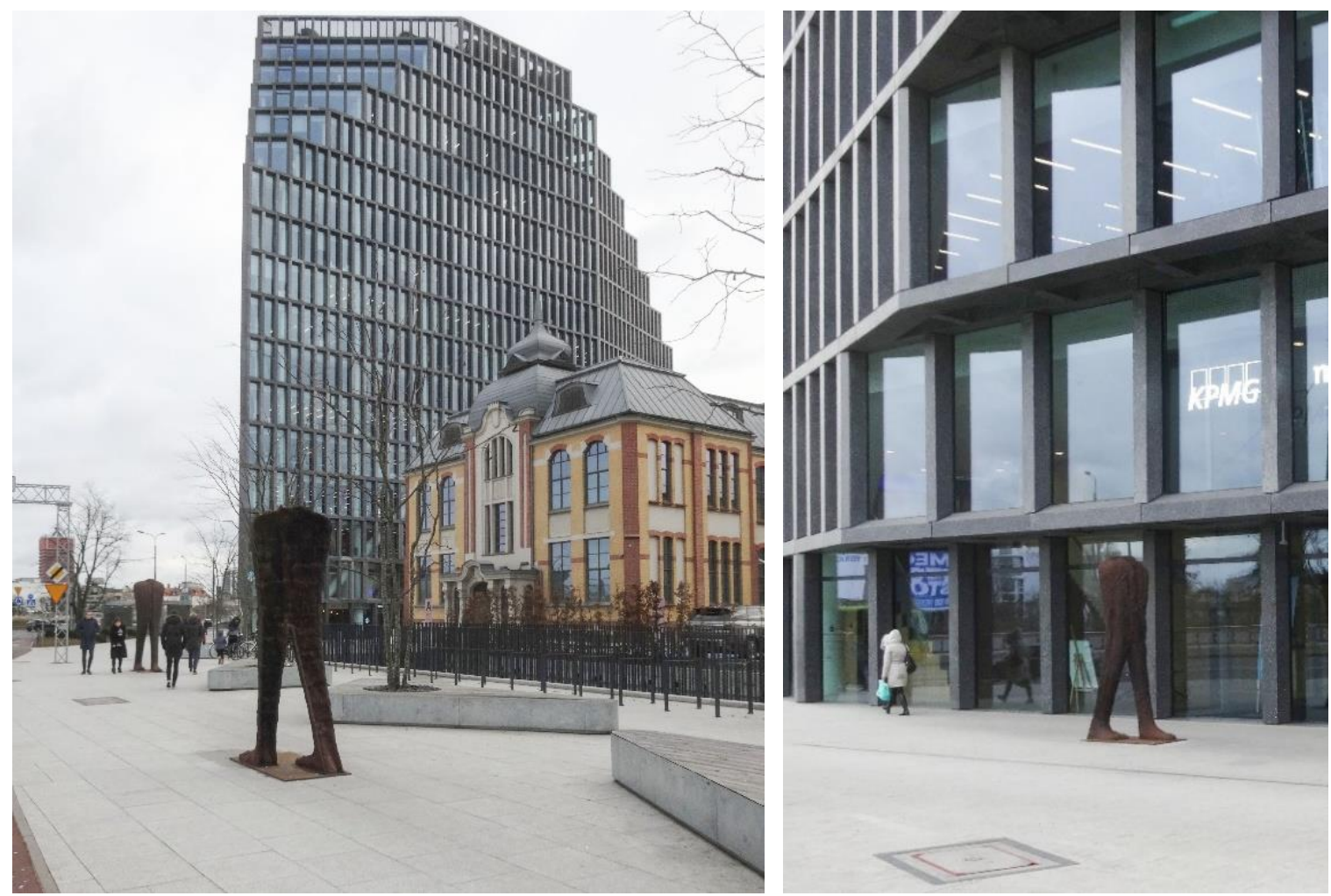

Fig. 6, 7. The Unrecognized by Magdalena Abakanowicz in front of the "Baltic" building. Source: Photo: M. Gyurkovich 2018

Ryc. 6, 7. Nierozpoznani Magdaleny Abakanowicz przed Budynkiem „Bałtyku”. Źródło: fot. M. Gyurkovich 2018

The essay by Adolf Loos of 1910 "Ornament and Crime" (Loos A., 2013, p. 133) is a manifesto of the architect against styles in architecture that he considers as equivalent to ornaments. According to Loos, ornaments and elaborate details should be removed, especially from utility objects. He considers it to be a necessary evolution of culture (Loos A., 2013, p. 136). His manifesto is a kind of censorship, as the subsequent architectural styles will use elaborate details (sculptures, paintings) in the arrangement of city interiors to a lesser extent. Since that time, the location of sculptures in urban spaces has been determined rather by symbolic aspects than the will to create the beauty of a composition.

\section{THE CITY - A SPACE DISPLAYED}

The end of the $17^{\text {th }}$ century and the $19^{\text {th }}$ century brought a development of exhibition spaces. Numerous galleries and museums were established that have presented works of art collected by generations, artefacts of material culture, scientific achievements, and many other exhibits until the present day. The accessibility of the collections to citizens was very important: the works of art that had been collected by few until then became publicly accessible. Collections of paintings, graphic, ornamental fabrics, and sculptures from the royal gardens were displayed in public (Borusiewicz M., 2012, p. 32).

Until then, people could see works of masters, e.g. painters, only in sacral buildings. However, as far as sculpture is concerned, it was not only sacral spaces that enabled to experience it. Since the ancient times, cities were equipped with excellent sculpture arrangements, monuments and fountains. The representative "salons" of cities were obviously the first publicly accessible sculpture galleries. 


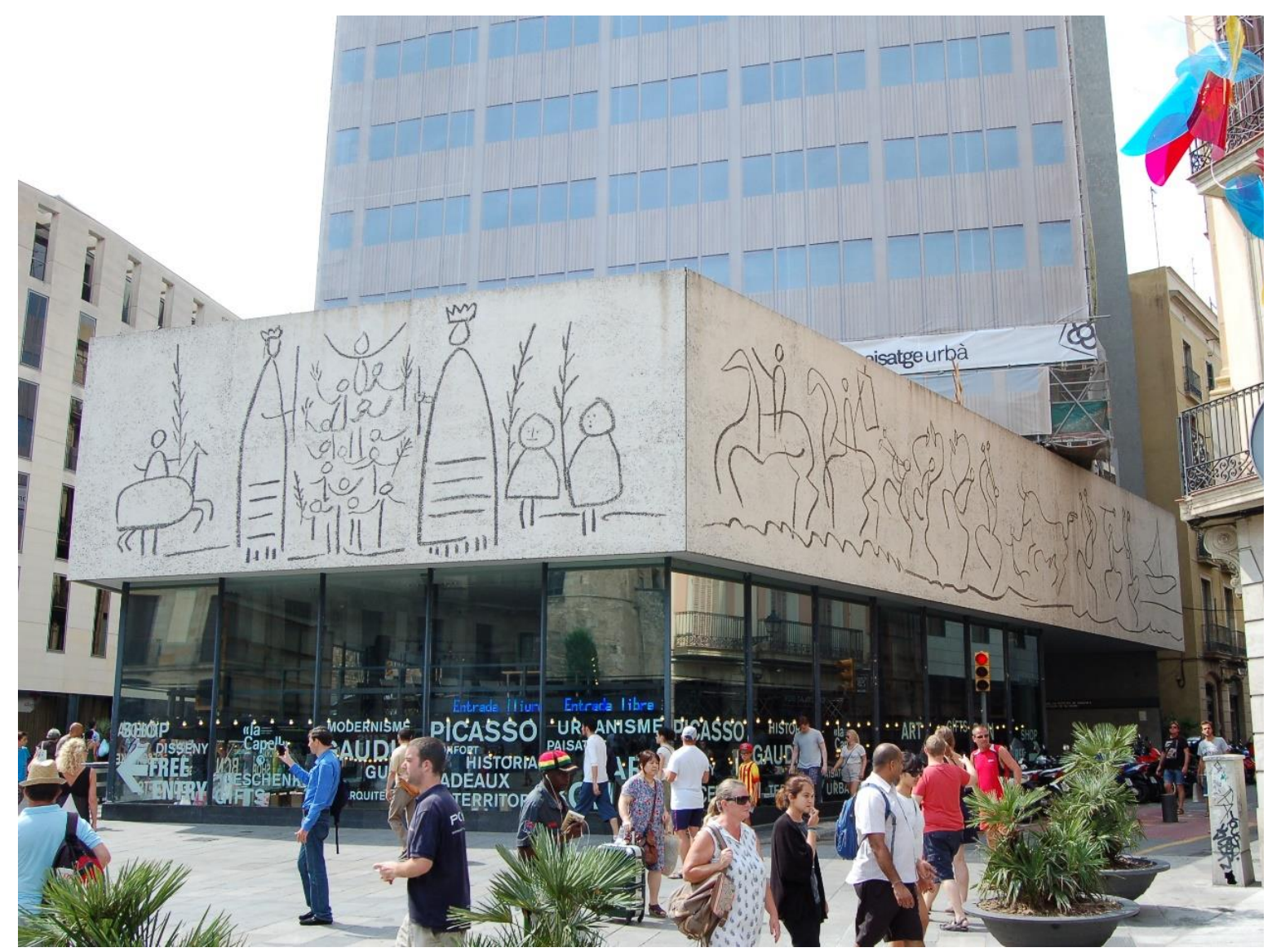

Fig. 8. University of Architecture Catalonia, sgraffito by Pablo Picasso. Source: Photo: M. Gyurkovich 2013 Ryc. 8. Uczelnia Architektury Katalonia, sgraffito Pablo Picassa. Źródło: fot. M. Gyurkovich 2013

This is proven, for example, by the sculptures by Phidias, the lions guarding the Lions' Square on Delos Island (Watkin D., 1996, p. 40), the reports about the Colossus of Rhodes, and a multitude of monuments and sculptures. Although most of the ancient monuments were dedicated to gods, heroes and rulers, in ancient Greece, and later in Rome, also secular sculptures were created. The home towns of Olympic Games winners honoured them with sculptures, and statues of senators and commanders were placed on Roman forums.

In the Renaissance period, which drew deeply from the traditions of the ancient era, and in the later Baroque period, sculptures, monuments, and water elements, apart from their aesthetical or ideological values, became important elements of the urban arrangements. The statue of the condottiero Gattamelata on a horse by Donatello, located on the square in front of the Basilica in Padua became a milestone in the history of town-planning (Żórawski J.1962, p.124). It combined the sculptor's artistry with excellent spatial arrangement. The monument allowed putting the space in order, to close the axes of the streets coming into the square, and to unite the broken space of the square in front of the church. This is an example of a site consciously dedicated to the exhibition. Thanks to considering the proportions of the square, the relationship between the dimensions of the interior walls, the analysis of compositional axes, and enhancing the expression of the form by raising the sculpture on a properly chosen pedestal, a synergy between the object and the location was achieved. Donatello chose the site by moving aside from the axis of the Basilica to honour it as an element that equally deserved a proper display. All these actions highlighted the artistic values of the monument, at the same time arranging and unifying the space (Żórawski J.,1962, p.133). 
In the Renaissance and Baroque periods the sculptural values were consciously combined with an awareness of the requirements of urban composition. This is when one of the spectacular open-air sculpture galleries was created - i.e. Rome of the Baroque period. Here, the Pope ordered to place Egyptian obelisks on pilgrimage yards of churches to mark the routes of pilgrimages, and fountains with elaborate sculptures started to appear in the public spaces. With time, this sculptural "furniture" has become one of the landmarks of Rome, which was then followed by numerous other European cities.

The Four Rivers fountain by Bernini was located in the central point of the Piazza Navona in Rome (a former Roman circus) (Watkin D., 1996, p. 246). It consists of an Egyptian obelisk, as in many other places of the Holy City, which was mounted on a heavily sculpted base. The composition of the square, which is an elongated rectangle, is complemented by two other fountains with equally rich sculptures. The linear arrangement enhances the axis of the square, and a strong dominant sets the centre of gravity.

What distinguishes this square interior is the fact that its characteristic cross-sections resemble rather those of a street instead of a square, forming an elongated exhibition hall. The central Baroque complex with its one-storey composition matches the transverse arrangement of the square, while the obelisk complements the long axis of the square and the bell towers of the Santa Agnes church. The two-element structure of the sculpture arrangement responds with a relationship to all walls of the square and interior elements. Another example located nearby is the Piazza dei Fiori, where a statue designed by Ettore Ferrari was erected in a central point, too, to commemorate Giordano Bruno, who was executed there. This much smaller, square-shaped piazza with even frontage lines, but very diverse buildings, required the artist to use a completely different set of solutions. The figure of the philosopher was raised on a massive pedestal, while creating a very cohesive, concentrated sculpture. The resulting form is characterised by vertical dynamics, but an equally massive shape. One may easily understand the sculptor's intentions when the square is full of its everyday life, with a market selling flowers, fruits, and vegetables with the figure of the philosopher towering above it.

The statue of the executed humanist brings us to another, equally important aspect of the city-gallery, which is the overlapping of symbolic, historical, and cultural layers. Monuments founded to commemorate people or events usually have the form of sculptures. The more historical the given place is the more difficult it becomes to choose the right form of the sculpture, as the architectural and historical context often accompanies the historical aspects. This is particularly important in contemporary realisations, when a new object is to be included in a historical cultural and architectural space. The more noble the place, or the exhibition site, and the more it is historically conditioned, the more difficult it becomes to select the right form. The activity of the "background" of the location gains new, abstract meanings and multi-faceted contexts, apart from its actual physical properties. The choice between narrative and illustration, symbolism and representation, becomes an important element of selecting the means of artistic expression and form.

The initiators of Rome's reconstruction in the Baroque period used the belfries of newly built and historic churches to mark pilgrimage routes. They also introduced Egyptian obelisks into the city structure. Apart from their artistic, symbolic, or compositional function, as it was in the case of the Piazza Navona mentioned above, tall monuments, due to their scale, became part of the city layout, becoming landmarks.

After the Ancient era, the Renaissance and Baroque periods proved the role of sculptures in the composition of urban spaces once again. However, they did were not always monuments of historical or religious importance. The arrangements were dedicated to individual spaces, with the aim to improve their quality. These experiments were continued and developed in the subsequent centuries. The end of the $18^{\text {th }}$ century and the $19^{\text {th }}$ century was the age of developing a new type of institutions designed for exhibition purposes, such as museums and art galleries. Until that time, the city had been a natural publicly available space, apart from the temples, where people could contact works of art. The process of developing the ways to shape the space of such object began. The first solutions were similar to those used to shape and decorate palace interiors. The first private gallery Ufitzzi (Borusiewicz M., 2012, p. 27), had been built a long time before that for the Medici family. The top floor of a building that accommodated clerks' offices was adapted for this purpose. Starting from the 
beginning of the $19^{\text {th }}$ century, when the first buildings dedicated to exhibitions were erected, the development of these objects drew from various models of organising space. New patterns were developed for the interiors and spatial arrangements inside the museums. What became important was the choreography of the viewer's walk, or creating a specific path of experiences.

\section{THE RELATIONSHIP BETWEEN THE EXHIBIT AND THE EXHIBITION SPACE}

\subsection{The analogies between exhibition spaces in cities and exhibition facilities}

The basic types of arrangement of exhibition spaces have been identified. Five basic schemas may be distinguished (Hoffman H. W. 2016, p. 56):

- circuit - the rooms are organised around a yard, and the visitors follow a closed path from one room to another, with the entrance and exit in the same place;

- linear - the rooms are arranged in line, the viewer follows a pre-determined axis, moving from one room to the next one;

- network - the rooms are connected in a linear way, but they are located on crossed axes, so the visitor may explore the structure according to their own plan, limited only by the exit and entrance from the arrangement;

- hierarchical space - one big hall that allows to enter smaller exhibition spaces. To move from one room to another, the viewers have to cross the main exhibition space;

- open plan - a single large space, whose form does not define the path of the visitors.

The presented layouts correspond to the organisation of the space in the building. An element that links it strongly to the public space is the fact that structural solutions depend on the movements of the visitor at the place of exhibition and on the paths of a city inhabitant. The space is arranged for its functions and to please the eye. The layout of museums has been shaped by numerous patterns. City structures are far references, but some analogies to the public spaces used to present works of art may be noticed. The circuit arrangement shows certain analogies to market squares with a centrally located town hall, where the zone of the square may be interpreted as interrelated interiors. One of the examples may be the Poznan Market Square, which is an exhibition space for 7 fountains and sculptures. Its linear layout corresponds to the public spaces of main streets that consist of a series of consecutive urban interiors. Another example is the Krakowskie Przedmieście Street in Lublin (Wejchert K. 1984, p. 170). It is, however, difficult to find clear analogies to urban space arrangement in the network layout: the analogy can be found in connected yards and courtyards. A similar situation is with the hierarchical layout in urban space: it may be noticed in the historical structures of series of market squares or squares connected by the main square or a network of streets. The square, market square or the agora bear the strongest resemblance to the single-space layout. One of such interiors is also the roof of the cathedral in Milan, which was adapted as a space to display modern sculptures. It is an extraordinary combination of a Gothic cathedral and contemporary objects, with the cityscape acting as the background for this dialogue (Fig. 4, 9).

Table 1. Presentation of the analogies between exhibition facilities and urban structures. Source: own study

\begin{tabular}{|l|l|l|}
\hline Type of exhibition & Space in museums and art galleries & Urban spaces \\
\hline Circuit & $\begin{array}{l}\text { Exhibition rooms are arranged around a } \\
\text { courtyard or staircase. }\end{array}$ & $\begin{array}{l}\text { Market square, a square with a centrally } \\
\text { placed architectural object. }\end{array}$ \\
\hline Linear & $\begin{array}{l}\text { Corridor or hallway arrangement of the exhi- } \\
\text { bition. }\end{array}$ & Streets, avenues, elongated squares. \\
\hline Hierarchical & One main hall with adjacent exhibition rooms. & $\begin{array}{l}\text { Main space interconnected with other ur- } \\
\text { ban interiors. }\end{array}$ \\
\hline Network & $\begin{array}{l}\text { A set of equally important exhibition spaces, } \\
\text { which the viewers may choose freely. }\end{array}$ & A set of available courtyards. \\
\hline Open plan/hall & Single-space exhibition hall & Open square or market square \\
\hline
\end{tabular}




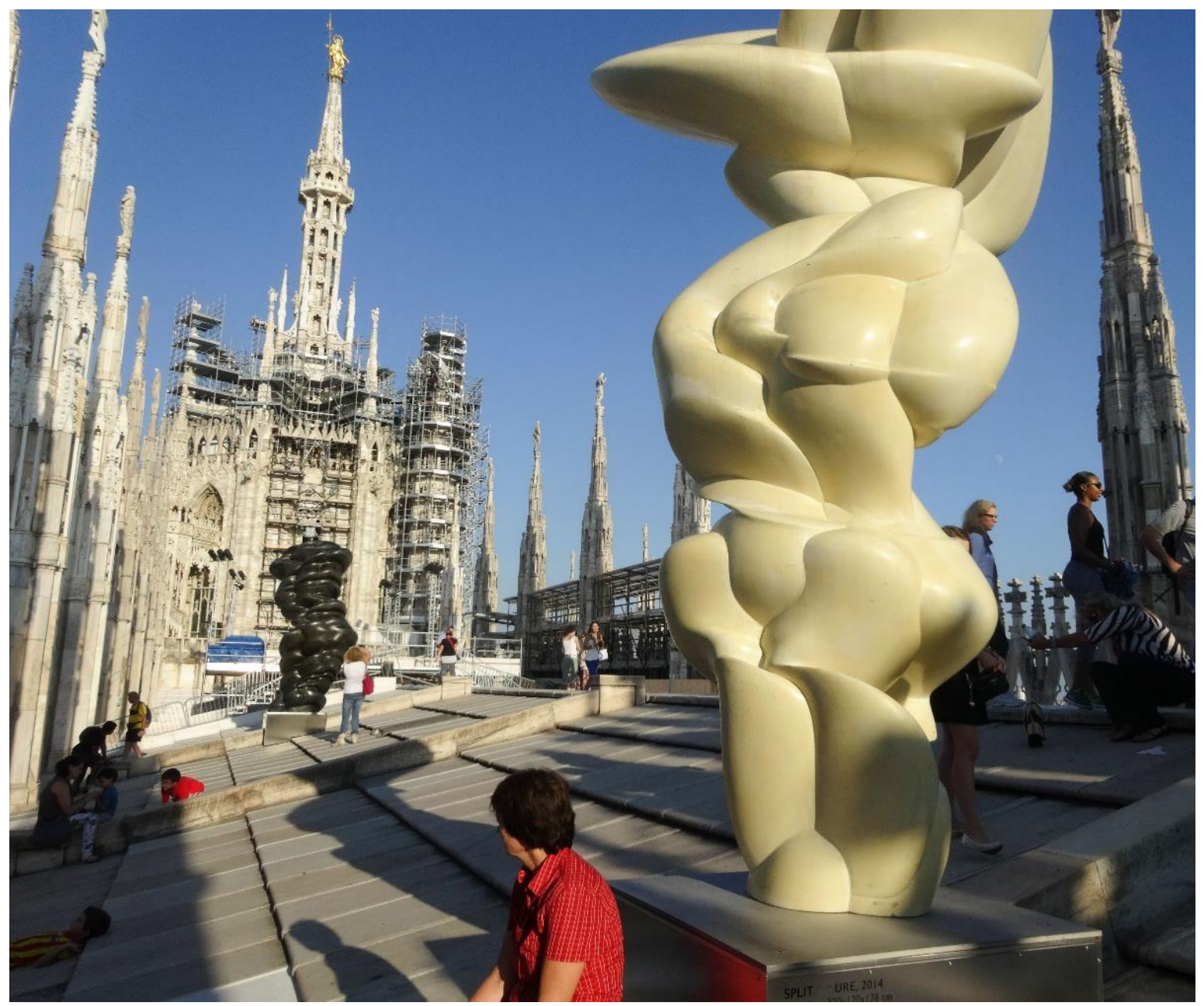

Fig. 9. Sculptures on the roof of the Cathedral in Milan. Source: Photo: M. Gyurkovich 2015

Ryc. 9. Rzeźby na dachu Katedry w Mediolanie. Źródło: fot. M. Gyurkovich 2015

\subsection{Exhibition strategies in arranging urban exhibitions}

Three approaches or strategies may be distinguished in designing the exhibition space:

- detail-oriented - focusing on the exhibit and its nearest surroundings,

- narrative-oriented - where the content or telling a story becomes the most important,

- space-oriented - the essence is composing and building relationships between the object and the site and between other displayed objects.

The same approaches may be found in the concepts of presentation in urban spaces. Informational or commemorative exhibitions are examples of using the first strategy. The quality and form of the presentation concept determine the perception. The manner of displaying focuses on what is presented, not on the location: a city square or market square, or a street. The equivalent of such approach in cities is placing the works of art with reference to the closest exhibition plane, without any wider references, and when the decisions are focused on the work and its author.

The narrative approach is dominated by the content, and communicating it becomes the main goal. The rank and content of the story influence the location, scale, references, or their absence. The statue of Karol Marcinkowski in Poznan (Fig. 11) is a contemporary example of such decisions (Poznań, 2018). 


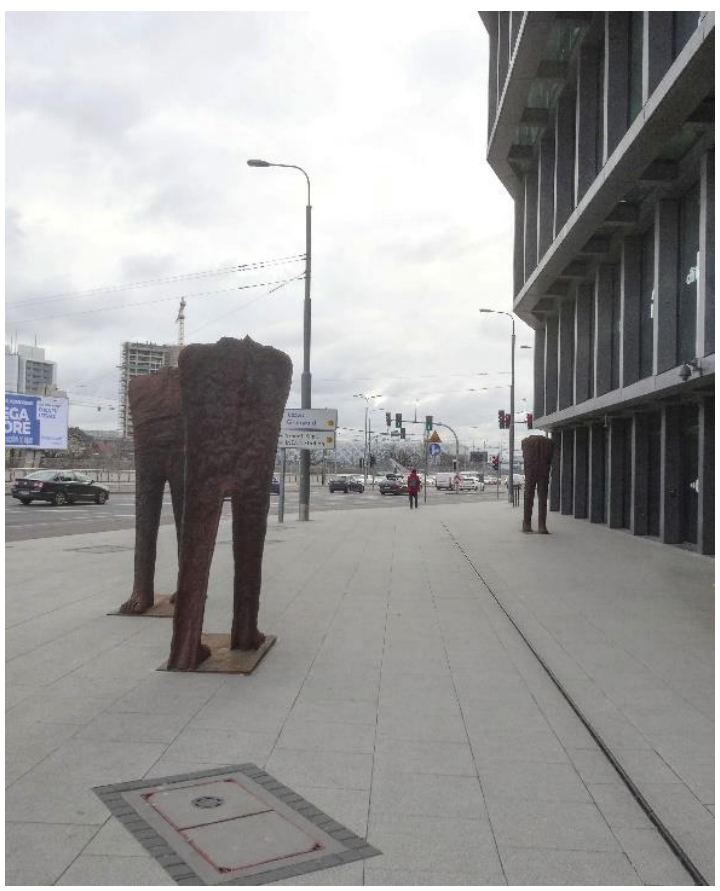

Fig. 10. The Unrecognized by Magdalena Abakanowicz in front of the "Baltic" building. Source: Photo: M. Gyurkovich 2018

Ryc. 10. Nierozpoznani Magdaleny Abakanowicz przed budynkiem „Bałtyku”. Żródło: fot. M. Gyurkovich 2018

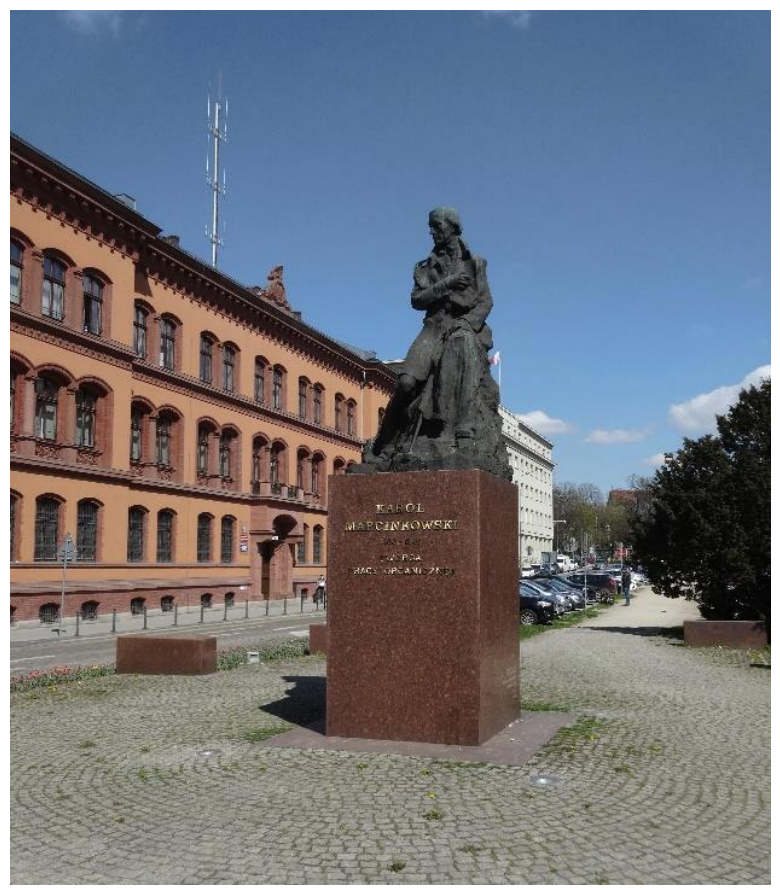

Fig. 11. The statue of Karol Marcinkowski in Poznan. Source: Photo: M. Gyurkovich 2021

Ryc.11. Pomnik Karola Marcinkowskiego w Poznaniu. Źródło: fot. M. Gyurkovich 2021

The third strategy enables to seek harmony in the work of art and to improve the values mentioned above. As the points of reference expand, many important factors emerge. Displaying works of art requires selecting the appropriate means and manner of presentation. In the neutral spaces of museums and art galleries sculptures are displayed according to various selection criteria, such as the author, the period, the art trend, historical context, the purchase chronology, the owner of the collection, cultural context, or the size and dimensions of the collection. The aim of all these criteria and actions is to highlight the artistic values of the object, the expression of form, and to enhance the clarity of the selected collection. The viewers contact the works of art "face to face" in an environment that has been created especially for this purpose, which should interfere with the exhibit as little as possible. Such prepared space allows to control not only the spatial arrangement, colour, lighting, and the number of visitors, but also the sound or smell and permanence. Urban spaces do not offer such comfortable conditions, as the possibility to control the dynamics of changes in the environment is limited. One may search for a specific location for the given object, or look for an appropriate object for the chosen space. Although the surroundings or the sculpture form are selected, the aspect of changeability remains strong. It is difficult to find uniform background for the display in urban spaces, as every façade or every view may differ from the other or it may change with time, like, for example, a wall of greenery that changes with the seasons.

Apart from the changeable background, other important factors are the distance from the background and the relation of scale. Distance enables to strengthen or weaken the relationship with the background, i.e. to decide on the background on which the object will be displayed. In general one may distinguish three cases:

- The distance that exists between the object and the background allows to establish relations between forms and scales. At the same time, each of them is clearly a separate object that has 
its own space of perception. One of the best examples is the statue of arcus Aurelius at the Capitol.

- The separation from the background is characteristic for landscaping arrangements, objects located in squares or on the axes of roads. The distance between the element and the wall is much larger than in the first case. In most exhibition frames, the background is the sky, the floor, or decidedly distant frontage or architectural object.

- The relationship of immersion, an intentional strong dialogue with the background. This is the well-known case of sculptures that were created as integral elements of architectural objects or arrangements. In common realisations, this approach was used in the arrangement of sculptures "The Unrecognized" that was mentioned before, or the huge blue bear leaning against the glass façade of the building (the sculpture "I see what you mean" by Lawrence Argente in Denver, USA. (Pluta K., 2012, p. 224).

\subsection{The exhibition of the works of Igor Mitoraj}

In 2003, the sculptures by Igor Mitoraj were presented in three Polish cities. The exhibition spaces for the largest works were the interior of the Old Market Square in Poznan, the Market Square in Krakow, and the internal and external courtyards of the Royal Castle in Warsaw.

The first exhibition of this unique-scale event took place in Poznan. Special cement foundations were prepared in the square $s$ that the sculptures could be mounted in a stable way. The exhibition was arranged on the western and southern sides of the Old Market Square. The sculptures were presented on cobblestone paving. The western part was a linear arrangement of several sculptures facing the central part of the square, and compositionally aligned with the background of townhouses. The second part of the exhibition consisted of sculptures placed at a distance from each other, which differed in terms of size and form, but were still arranged to match the urban walls of the interior. The arrangement was very consistent and consequent in terms of exhibition decisions. The remaining part of the exhibition was displayed in the National Museum in Poznan (Fig. 1, 2, 5, and 12).

In 2004, 14 works of the artist were presented in the Main Market Square in Krakow (Badach, 2004, p.71). The composition was arranged by searching for the right place for each of the objects. The space of the interior and the size of the collection allowed for building several unique relationships between the sculptures and the space. The presentation was arranged on a large part of the market square, the exhibits were placed on the main axes, and a group was composed in the north-western part, in the central section of the interior floor, separated from the interior walls. Further sculptures found their place in relationships with the background, e.g. of the St. Adalbert Church. The Krakow exhibition presented a whole palette of town-planning and display solutions. The open air presentation was complemented by the exhibition in the town house "Pod Krukiem".

The exhibition in Warsaw was the largest and most scattered one. The exhibition in urban space was presented in the Royal Castle Square. As opposed to the previous locations, here part of the exhibition was displayed on the soft ground of the square. The linear arrangement of sculptures built the articulation. What is interesting is the fact that, while in Krakow and Poznan the objects were arranged towards the space, the sculptures displayed in Warsaw were facing each other. The head, placed against the façade of the Royal Castle, in a demanding, lowered exhibition space, was perfectly displayed. The internal courtyard and its relationship with the external square provide an analogy to the hierarchical layout, whereas the internal composition was strongly related to the background (Fig. 13-15).

Urban spaces became extraordinary exhibition spaces for displaying the works of one artist at the same time. These three urban spaces served as exhibition laboratories, and each of them used an individual approach to space. Such space-sensitive approach allowed the works of Igor Mitoraj to play the main role in the dialogue with beautiful, historical sites. 


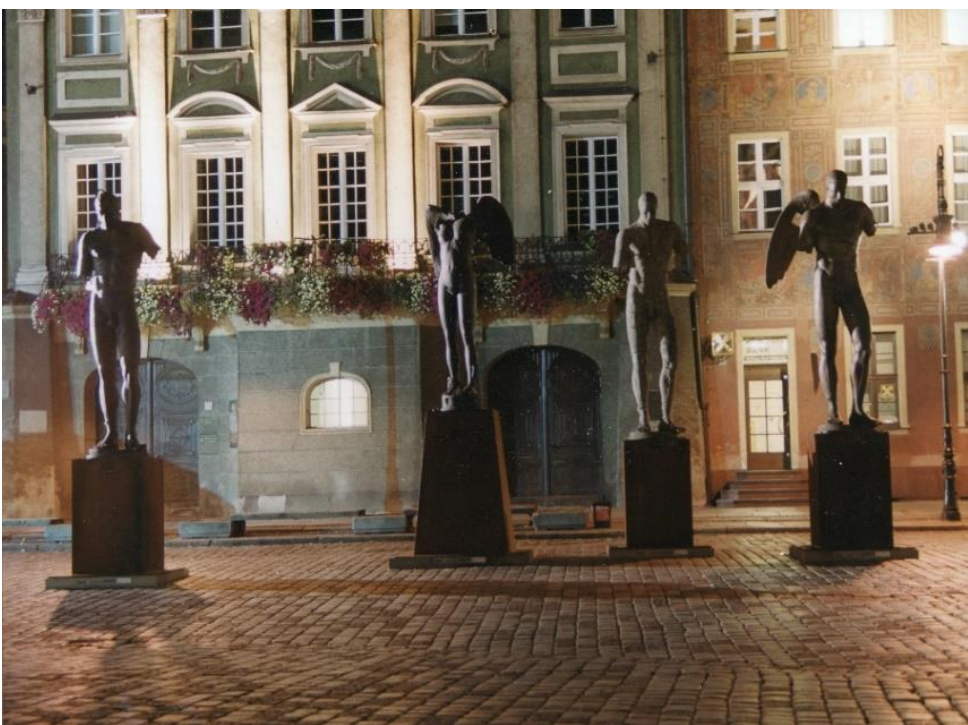

Fig. 12. Exhibition of Igor Mitoraj's sculptures, Poznań. Source: Photo: Z. Kosicki 2003

Ryc. 12. Wystawa Mitoraja Poznań. Źródło: fot. Z. Kosicki 2003

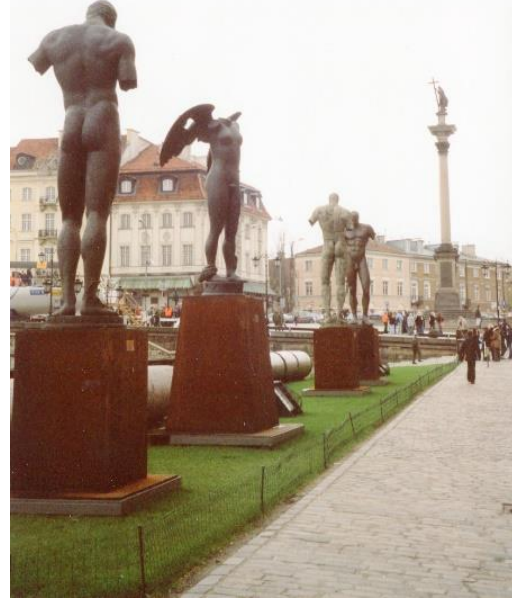

Fig. 13. Exhibition of Igor Mitoraj's works in Warsaw. Source: Photo: Z. Kosicki 2004

Ryc. 13 Wystawa Mitoraja Warszawa. Żródło: fot. Z. Kosicki 2004
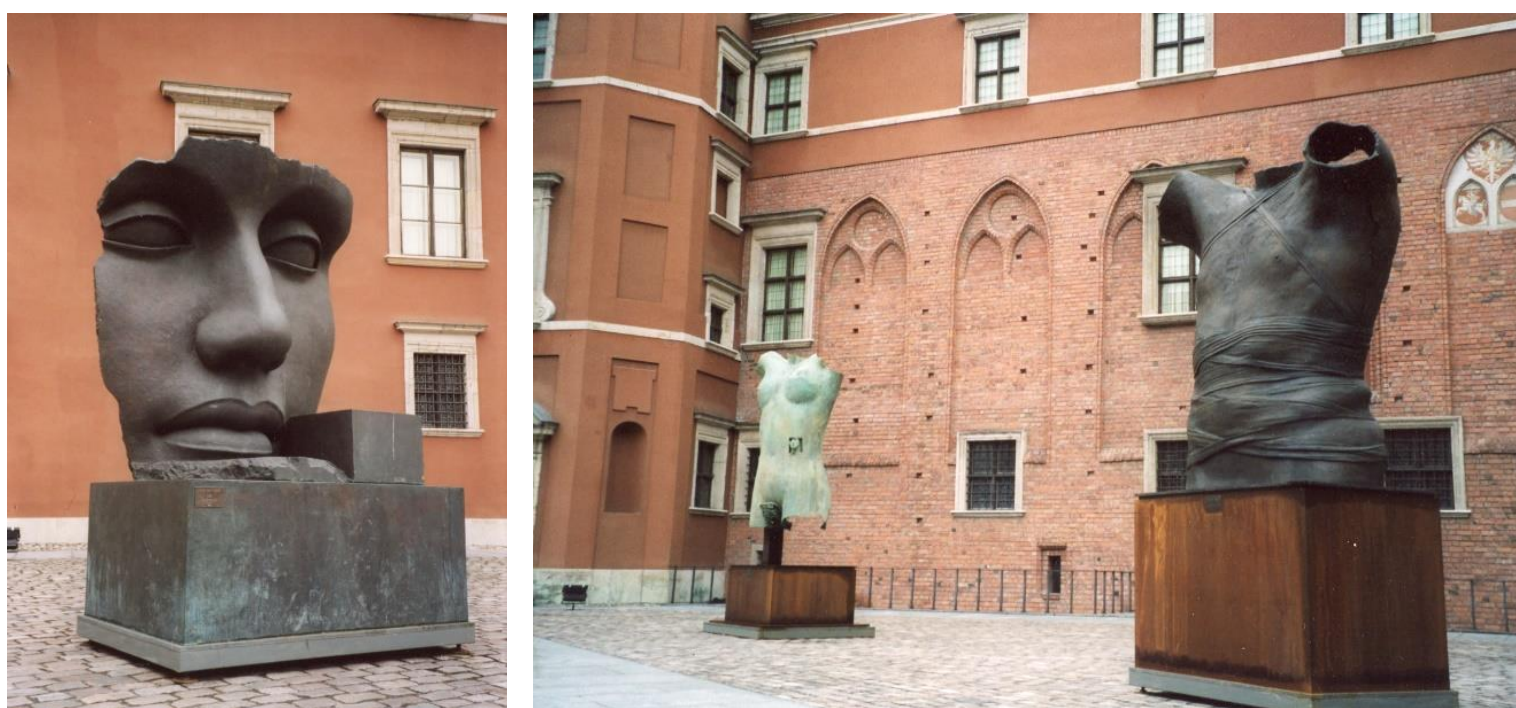

Fig. 14, 15. Exhibition of Igor Mitoraj's works in Warsaw. Source: Photo: Z. Kosicki 2004

Ryc. 14, 15. Wystawa Mitoraja Warszawa. Źródło: fot. Z. Kosicki 2004

\section{CONCLUSIONS}

The scale of exhibition facilities is incomparable to that offered by the city as a gallery. The exhibitions discussed here reveal analogies between the shaping of exhibition structures and moving around in familiar structures. This works both ways. An example of a contemporary museum whose structure was inspired by the city is the realisation of the Louvre Museum in Abu Dhabi, designed by Jean Nouvel and opened in 2017 (Louvre Abu Dhabi, 2018). The paper presents the research on issues related to displaying works of art in public spaces from the point of view of exhibition experiences. 
This issue is discussed mainly as an element of the urban composition on a town-planning or symbolic scale. The exhibition-related aspects allow us to analyse urban spaces in a more intimate scale. The analogies between the structure of art displays in exhibition facilities and city structures have been presented. This allows us to analyse the city as a consciously designed art gallery, which may be contemplated and experienced, and which creates an attractive and recognisable space. Many different means may be used to achieve the goal, which is the search for harmony - beauty - between the displayed object, the background, and the space. However, not all aspects have been discussed, and the issue requires further research.

\section{MIASTO GALERIA BEZ BILETU. RELACJA OBIEKT EKSPONOWANIA A PRZESTRZEŃ EKSPOZYCJI}

\section{WSTĘP}

Inspiracją do przeprowadzonych badań była prezentacja rzeźb Igora Mitoraja w roku 2003 w Poznaniu (Mitoraj, 2003)oraz w Krakowie i Warszawie 2004 roku (Badach,2004,s.71), które zostały wyeksponowane w przestrzeni miejskiej na Starym Rynku w Poznaniu, na Rynku Głównym w Krakowie oraz na zewnętrznym i wewnętrznym Placu Zamku Królewskiego w Warszawie. Prezentacja siedemdziesięciu rzeźb miała również miejsce we wnętrzach ekspozycyjnych, natomiast to przestrzenie publiczne trzech miast polskich stały się na moment głównymi „salami” wystawienniczymi. Unikatowa pod względem skali ekspozycja jednego artysty, zaaranżowana w ogólnie dostępnej przestrzeni, żyjącej swoim codziennym życiem, ukazała rynki i place jako interesujące, pobudzające otoczenie wystawiennicze. Dzieła Mitoraja znakomicie wpisały się w skalę i proporcje miejsca, zaś ono nadało prezentacji dodatkową niepowtarzalną historyczną narrację (ryc. ryc.1,2,5,12-15). W swoich dziełach Mitoraj sięgał do odniesień zaczerpniętych w antyku i renesansie, współgrały one z miejscem eksponowania. To wydarzenie artystyczne nie jest czymś niespotykanym. W przestrzeniach miast odbywają się prezentacje dzieł sztuki (ryc.3,4,8), performensów, wydarzenia teatralne czy wystawy jako wydzielone strefy prezentacji w różnych skalach. Rzadko udaje się uzyskać spójność urbanistycznego otoczenia i czasowej prezentacji, częściej jest to możliwe dla lokalizacji obiektów pojedynczych lub stałych lokalizacji.

O pięknie miasta decyduje jego kompozycja, proporcje wnętrz urbanistycznych, wysoki poziom obiektów architektonicznych oraz zaaranżowana zieleń (Bardzińska-Bonenberg, T., Sobczyńska, K. 2018, s. 10), jak również rozwiązania komunikacyjne oraz niezliczona ilość innych czynników. Nieodzowną składową w postrzeganiu miasta jest również jakość życia mieszkańców, na którą składają się czynniki bytowe, poczucie bezpieczeństwa, komfortu. Równie ważna w percepcji przestrzeni jest jakość estetyczna. Kontakt z dziełami sztuki może podnosić wymienione walory. Role, jakie mają one spełniać, są różnorodne, towarzyszą nam jako:

- dzieła architektoniczne i ich lokalizacja silnie wiąże się z kompozycją urbanistyczną

- detal rzeźbiarski lub malarski budowli

- obiekty z odniesieniami narracyjnym to te, które służą upamiętnieniu wydarzenia, osoby ich lokalizacja jest silnie związana $z$ treścią lub prestiżem miejsca

- dzieła sztuki (rzeźby, murale, meble miejskie) wyposażają przestrzeń miejską, podnosząc jej walor artystyczny. 
Relacja między wymienionymi rodzajami a przestrzenią, w jakiej sa eksponowane, w istotny sposób wpływa na ich odbiór. Opisując działania, w jaki sposób te obiekty się pojawiają, mówimy o: umiejscowieniu, lokalizacji, posadowieniu, ustawieniu a może powinno być eksponowanie, wystawienie, prezentowanie. Jest to z pozoru gra słowami, ale w budowaniu relacji przestrzennych, ekspresji i narracji działają one na innych poziomach decyzji projektowych. O mieście, jako przestrzeni eksponowania (z wyłączeniem stref rekreacyjnych i parkowych ${ }^{2}$ ) i analogiach do wnętrz w budynkach ekspozycyjnych poświęcony jest ten artykuł.

\subsection{Metodologia}

W badaniach nad relacją eksponat przestrzeń eksponowania szczególne sa przypadki, kiedy miejsce i obiekt są równie ważne, równie istotne w percepcji. Rzeźby, malarstwo ścienne są w komponowane w przestrzeń miasta jak element kompozycji, jego narracji estetycznej lub symbolicznej. Przypadek wystawy Igora Mitoraja to przykład czasowej ekspozycji odświeżającej wnętrza rynków i placów. Dla zrozumienia czy miasto jest galerią zwiedzaną codziennie bez biletu i ograniczeń przyjęto metodę badań mieszanych w tym: przegląd literatury, obserwacyjna analiza historycznych rozwiązań, analiza porównawcza oraz analiza przypadku wystawy w 2003 roku w Poznaniu i 2004 roku w Warszawie, oraz Krakowie.

\section{OBIEKT SZTUKI W MIEŚCIE WYZWANIE, POTRZEBA}

Miasta to ludzie (Gehl J., 2014, s. 25) dotychczasowy ich rozwój doprowadził do wyludniania się centrów, wynika to z rozrastania się miast, rozproszonych funkcji, nowych funkcji, sposobu komunikacji i wielu innych. Ludzie zbierają się tam, gdzie się coś dzieje, gdzie powstają pozytywne doznania (Gehl J., 2014, s.77). Różnorodny detal, atrakcyjne wyposażenie przestrzeni publicznej według badań Jana Gehla, przekłada się na zwiększenie aktywności i uczestnictwa mieszkańców tej przestrzeni. Dzieła sztuki są używane do aranżowania takich miejsc, ale samo ich pojawienie się nie oznacza sukcesu; przykład niewygodnej ławki, na której sadza się rzeźbę, aby mieć pewność, że ktoś w tym miejscu siedzi (Gehl J., 2014, s. 144) jest przykładem wypełniania przestrzeni zamiast eksponowania.

Przestrzenie publiczne są miejscem zróżnicowanych zjawisk, związków i potrzeb. Kształtują ich charakter i są współczesną odpowiedzią na potrzeby miasta. Z punktu widzenia badań nad przestrzenią publiczną Katarzyna Pluta (Pluta K., 2012, s. 231) wyróżnia między innymi:

- Harmonijny związek dzieł sztuki

- Dominującą oryginalność obiektu architektonicznego w przestrzeni publicznej.

- Obiekty architektoniczne stanowiące tło współczesnych rozwiązań przestrzeni publicznych, czyli nowego krajobrazu miejskiego.

Badaczka odnosi tę zależność do relacji dzieło sztuki, jako obiekt architektoniczny w relacji do przestrzeni publicznej. Zidentyfikowane relacje odpowiadają również dziełom sztuki innym niż architektura. Harmonia to swoista zależność, która podnosi jakość miejsca, uwypukla jego piękno, ale i również porządkuje relację, która ukazuje obiekt i służy jego otoczeniu. To jedna z bardzo istotnych różnic w eksponowaniu w przestrzeni miasta porównaniu do obiektów wystawienniczych. W muzeum, galerii celem jest ukazanie eksponatu, w przestrzeni publicznej istotne jest to, co staje się z miejscem, w którym pojawia się obiekt. Idealnym stanem jest, kiedy eksponowaniu podlega obiekt, miejsce i tło, ekspozycja rzeźb Mitoraja to przykład takiej harmonii synergii miejsca, rzeźb i historycznego tła (ryc. 1, 2, $5,12)$.

„Dominująca oryginalność” to relacja, która uniemożliwiać wyeksponowania czegokolwiek na takim tle, jak również zbyt dominująca forma na przykład rzeźbiarska może przesłonić tło, uniemożliwiając dojście do harmonii, rzeźba Richarda Deacona „Between Fiction and Facts” Vieleneuve-d'Aacq we Francji jest przykładem takiej dominacji (Uffelen Ch., 2012, s. 136). Dominowanie oryginalnością,

\footnotetext{
${ }^{2}$ Artykuł dotyczy relacji obiekt eksponowania a przestrzeń ekspozycji w zwartej części miasta, tereny rekreacyjne i parkowe wymagają oddzielnego opracowania.
} 
skalą, ekspresją to ekspozycja z akcentem na jednego „aktora” i może przynieść dla przestrzeni pozytywne wartości, jeden przewodni gest - forma może nadać charakter miejscu, odsunąć na plan dalszy dysharmonię relacji, wyznaczyć oś kompozycji. Taką rolę odgrywa wiele monumentów szczególnie służących do zaznaczenia faktu historycznego, politycznego, ale jest również Fontanna Trevi (Rzym) dzieło Nicola Salvi, która zawładnęła, zdominowała przestrzeń, nadała jej charakter (Uffelen Ch., 2012, s. 44).

Jan Gehl zauważa istotę krawędzi miasta - styku pomiędzy przestrzenią publiczną a miastem i jej rolę, jakości dla podtrzymania intensywności wrażeń (Gehl J.,2014, s. 75). Tło, jakim są pierzeje ulic placów, może oddziaływać w różnych planach ekspozycyjnych. To, co jest atrakcyjne na długiej osi ekspozycji, w bliskiej ekspozycji krawędź miasta i budynku bywa monotonna, nużąca, a często z powodu wymogów funkcji - martwa (np.: zasłonięte okna sklepów spożywczych). Ten newralgiczny moment staje się również okazją do ciekawych interakcji między obiektem eksponowanym a tłem. Przykładem takiego wzajemnego uzupełnienia jest aranżacja rzeźb „Nierozpoznani” Magdaleny Abakanowicz przed główną elewacją nowoczesnego budynku „Bałtyk” autorstwa MVRDV. Kompozycja pięciu odlewów zmiękcza „krawędź miasta”, odnosi się wrażenie, że w koncepcji aranżacji wzięto pod uwagę percepcje $z$ tego układu dla przechodniów i osób jadących jedną z głównych dróg Poznania. Jedna z rzeźb jest umiejscowiona bardzo blisko, następuje integracja obiektu i tła. Na podkreślenia zasługuje, że to miejsce należy do typowych przestrzeni służących komunikacji, wybrane dzieła wpisują się $w$ tę narrację i podnoszą znacznie jakość tego miejsca (ryc.6,7,10)

Ważne jest również to, że miasta przyspieszają, czas percepcji przestrzeni się skraca, wytyczane są szersze drogi, w odbiorze wiele detali się zaciera. Pogodzenie tempa miasta i nowych detali, jakie się w nim pojawiają tablice informacyjne, wskaźniki, reklamy staje się wyzwaniem w kształtowaniu sposobu eksponowania obiektów. Na ten aspekt zwraca uwagę w badaniach Anna Januchta-Szostak:

Wobec ujednolicania wzorców kulturowych obiekty sztuki wizualnej w przestrzeni publicznej przejmuje niezwykle odpowiedzialną role - krystalizacji mapy poznawczej miasta i budowy tożsamości miejsca (Januchta-Szostak A. 2207, s.53).

Esej Adolfa Loosa z 1910 roku „Ornament i zbrodnia” (Loos A., 2013, s. 133) jest manifestem architekta przeciw stylom $w$ architekturze, który uważa za równoważny $z$ dekoracją. Według Lossa ornament, rozbudowany detal powinny być usunięty szczególnie z przedmiotów użytkowych, uważa to za konieczną ewolucję kultury (Loos A., 2013, s. 136). Jego manifest jest rodzajem cezury, następujące style architektoniczne w mniejszy sposób będą używały rozbudowanych detali (rzeźbiarskich, malarskich), w komponowaniu wnętrz miejskich. O lokalizacjach rzeźba w przestrzeni miasta częściej decydują od tego momentu względów symboliczne, a nie budowa piękna jego kompozycji.

\section{MIASTO - PRZESTRZEŃ EKSPONOWANIA}

Koniec wieku XVII i wiek XIX przyniósł rozwój przestrzeni ekspozycyjnych, powstało wiele galerii i muzeów, prezentują one do dziś gromadzone przez pokolenia dzieła sztuki, świadectwa kultury materialnej, osiągnięcia nauki i wiele innych eksponatów. Powszechność - czyli dostępność zbiorów dla obywateli miała niebagatelne znaczenie, dotychczas gromadzone przez nielicznych dzieła stały się dostępne dla ogółu. Zbiory malarstwa, grafiki, ozdobne tkaniny i rzeźby z pałaców królewskich wystawiono na widok publiczny (Borusiewicz M., 2012, s. 32).

Dotąd jedynie w obiektach sakralnych można było obcować z dziełami mistrzów np. malarstwa. Jednakże w wypadku rzeźby to nie tylko przestrzenie sacrum były miejscem obcowania ze sztuką. Miasta już od czasów starożytnych wyposażano w znakomite kompozycje rzeźbiarskie, pomniki i fontanny. Reprezentacyjne „salony” miast były pierwszymi powszechnymi galeriami rzeźby.

Świadczą o tym np. rzeźby Fidiasza, czuwające Lwy z Placu Lwów na wyspie Delos (Watkin D., 1996, s. 40), świadectwa o kolosie z Rodos, niezliczona ilość pomników i rzeźb. W większości starożytne pomniki ustawiano dla bogów, herosów i władców, jednak w starożytnej Grecji, a później Rzymie powstawały również rzeźby świeckie; miasto zwycięzców igrzysk olimpijskich honorowało ich rzeźbami, na rzymskie forach stawiano posągi senatorów i dowódców. 
W renesansie głęboko czerpiącym z tradycji starożytności i późniejszym baroku rzeźby, pomniki oraz elementy wodne oprócz wartości estetycznych czy ideowych zaczęły być ważnym elementem kompozycji urbanistycznej. Do historii urbanistyki przeszła lokalizacja konnego posągu kondotiera Gattamelaty dłuta Donatella (Żórawski J.1962, s.124) na placu przed Bazyliką w Padwie. Kunszt rzeźbiarski został połączony ze znakomitą kompozycją przestrzenną. Umiejscowienie pomnika pozwoliło uporządkować przestrzeń, zamknąć osie wychodzących na plac ulic, sprzężył rozbitą przestrzeń placu przed świątynią. To przykład świadomego poszukiwania miejsca ekspozycji. Dzięki uwzględnieniu proporcji placu, relacji wielkości ścian wnętrza, analizie osi kompozycyjnych, podbiciu ekspresji formy poprzez uniesienie rzeźby na odpowiednio dobranym cokole; osiągnięto synergię między obiektem a miejscem. Donatello wybrał lokalizację, usuwając się z osi bazyliki, honorując ją, jako element równie wymagający eksponowania. Wszystkie te zbiegi posłużyły uwypukleniu walorów artystycznych pomnika, jednocześnie porządkując i jednocząc przestrzeń (Źórawski J.,1962, s.133)

W renesansie i baroku w niekwestionowany sposób łączono walory rzeźbiarskie ze świadomością wymogów kompozycji urbanistycznej. W tych czasach powstaje jedna ze wspaniałych otwartych galerii rzeźby, jakim jest Rzym okresu baroku. Tu dla wyznaczania tras pielgrzymek papież nakazał ustawienie egipskich obelisków na placach pielgrzymkowych kościołów, w przestrzeniach publicznych pojawiają się fontanny o rozbudowanych formach rzeźbiarskich. Z czasem to rzeźbiarskie umeblowanie stało się jedną z cech charakterystycznych Rzymu, a wiele miast Europy podążyło tą drogą.

$\mathrm{Na}$ placu Navona w Rzymie dawnym cyrku rzymskim ustawiono w centralnym punkcie fontannę Czterech Rzek dłuta Berniniego (Watkin D., 1996, s. 246) składającą się z egipskiego obelisku, tak jak w innych centralnych ważnych miejscach świętego miasta, osadzając ją na mocno rozrzeźbionej podstawie. Kompozycje placu o rzucie wydłużonego prostokąta uzupełniają dwie fontanny równie bogato rozbudowane rzeźbiarsko. Układ liniowy ekspozycji wzmacnia oś placu, silna dominanta wyznacza punkt ciężkości.

Specyficzne dla tego wnętrza placu jest to, że jego charakterystyczne przekroje przypominają bardziej przekroje ulicy niż placu, długiej sali wystawowej. Centralny barokowy zespół ze swoją parterową kompozycją wpisuje się w poprzeczny układ placu, za to obelisk współgra z długą osią placu i dzwonnicami kościoła Santa Agnes; dwuczłonowość kompozycji rzeźbiarskiej odpowiada relacją w stosunku do wszystkich ścian placu i elementów wnętrza. Wybierając przykład z niedalekiego sąsiedztwa na placu dei Fiori dla upamiętnienia spalonego na tym miejscu Giordano Bruno ustawiono pomnik według projektu Ettore Ferrari w równie centralnym punkcie. Znacznie mniejszy plac o rzucie kwadratu i równomiernym układzie linii pierzei, ale bardzo zróżnicowanej zabudowie, wymagał od twórcy pomnika zdecydowanie innej palety rozwiązań. Wyniósł on postać myśliciela na masywnym cokole, jednocześnie budując bryłę rzeźbiarsko bardzo zwartą, skupioną, powstała w ten sposób forma o wertykalnej dynamice, ale równie masywnej formie. Zrozumieć zamysł rzeźbiarza można, kiedy plac żyje swoim normalnym tętnem, kiedy odbywa się na nim targ kwiatów, warzyw i owoców, można wtedy zobaczyć górującą nad nim postać myśliciela.

Postać straconego humanisty doprowadza do innego równie ważnego aspektu miasta-galerii, nakładania się warstw symbolicznych, historycznych i kulturowych. Pomniki fundowane dla upamiętnienia wydarzenia, osoby przybierają w większości formy rzeźbiarskie. Im bardziej związane z historią miejsce, tym trudniejszy staje się dobór formy rzeźbiarskiej, oprócz aspektu historycznego często idzie w parze kontekst historyczno-architektoniczny. Szczególnie w realizacjach współczesnych ma to istotną wagę, kiedy w przestrzeń kulturowo i architektonicznie zabytkową ma zostać wpisany nowy obiekt. Im „miejsce”, czyli sala wystawowa jest znamienitsza i historycznie uwarunkowana, tym dobór form staje się trudniejszy. Aktywność „tła” lokalizacji, oprócz realnych fizycznych cech nabiera abstrakcyjnych znaczeń i wielowątkowych kontekstów. Wybór pomiędzy narracją a ilustracją, symboliką a przedstawianiem staje się istotny w doborze środków rzeźbiarskiego wyrazu i formy.

Twórcy przebudowy Rzymu w okresie baroku użyli do wyznaczenia dróg pielgrzymkowych dzwonnice nowo wzniesionych kościołów i istniejących świątyń, wprowadzili również w strukturę miasta egipskie obeliski. Wysokie monumenty nie miały tylko funkcji artystycznej, symbolicznej czy też kompozycyjnej jak w wypadku wspomnianego wcześniej placu Navona, ale swoją skalą wpisywały się w układ miasta, stając się land markami. 
Po okresie antycznym renesans i barok udowodnił ponownie rolę form rzeźbiarskich w kompozycji przestrzeni publicznych. Ich pojawienie nie było wyłącznie powodowane upamiętnieniem, znaczeniem historycznym lub religijnym. Kompozycje dedykowane były konkretnej przestrzeni, a celem podniesienie ich jakości. Te doświadczenia były kontynuowane i rozwijane w kolejnych wiekach. Koniec wieku XVIII i wiek XIX to okres rozwijania nowego rodzaju instytucji, przeznaczonych do celów ekspozycyjnych, jakim stały się muzea i galerie. Miasto do tego czasu było naturalnym, obok świątyń, miejscem powszechnie dostępnym, w którym można było obcować z dziełami sztuki. Rozpoczął się proces wypracowywania sposobu, jak powinno się kształtować przestrzeń takiego obiektu. Pierwsze wzorce to analogiczne rozwiązania wzorców pałacowych w kształtowaniu i dekorowaniu wnętrz. Pierwsza prywatna galeria Ufitzzi (Borusiewicz M., 2012, s. 27) powstała na zlecenie rodu Medyceuszy dużo wcześniej i na ten cel zostało zaadoptowane górne piętro budynku mieszczącego biura urzędników. W doświadczaniu i rozwoju od początku XIX wieku (wtedy to powstają pierwsze budynki dedykowane funkcji ekspozycyjnej) sięgano do różnych wzorców organizowania przestrzeni. Wnętrza i układy przestrzenne wewnątrz muzeów wypracowały nowe wzorce, istotna stała się choreografia przejścia widza przez nie, tworzenie swoistej ścieżki wrażeń ekspozycyjnych.

\section{RELACJA OBIEKT EKSPONOWANIA A PRZESTRZEŃ EKSPOZYCH}

\subsection{Analogie przestrzeni ekspozycyjnych w miastach i obiektach wystawienniczych}

W kształtowaniu ekspozycji zostały zidentyfikowane podstawowe schematy przestrzenie eksponowania, wyróżniamy pięć podstawowych schematów (Hoffman H.W. 2016, s. 56):

- obwodowy (circuit) - sale zorganizowane wokół jednego dziedzińca, zwiedzający poruszą się po domykającej się ścieżce z jednej sali do drugiej, wejście wyjście w tym samym miejscu;

- układ liniowy - sale ułożone są amfiladowo, z jednej przechodzi się do następnej, widz porusza się wzdłuż wyznaczonej osi;

- układ sieciowy - połączone w typie amfiladowym, ale sale ułożone są na krzyżujących się osiach, widz zwiedza strukturę według własnego planu, ogranicza go tylko wejście i wyście z układu;

- przestrzeń hierarchiczna - jedna duża sala pozwala na wejście do mniejszych sal ekspozycyjnych, widz przechodzi z sali do sali poprzez główną przestrzeń ekspozycji;

- otwarty plan - czyli jedna duża przestrzeń, której forma nie definiuje sposobu poruszania się widza.

Zaprezentowane schematy odpowiadają organizacji przestrzeni budynku, elementem zdecydowanie silnie łączącym z przestrzenią publiczną jest uzależnianie rozwiązań struktury od poruszania się widza w miejscu ekspozycji i mieszkańca w mieście, to organizowanie przestrzeni dla funkcji i oka. $\mathrm{Na}$ układ muzeów miało wpływ wiele wzorców, struktury miasta są dalekimi odniesieniami, ale widoczne są pewne analogie między przestrzeniami publicznymi, które służyły do prezentowania dzieł sztuki. W układzie obwodowym widać analogie do rynków z centralnie zlokalizowanym ratuszem, gdzie można odczytywać strefy placu, jako sprzęgające się wnętrza. Jednym z przykładów może być Rynek Poznański, który jest miejscem eksponowania 7 fontann i rzeźb. Liniowy układ odpowiada przestrzeniom publicznym głównych ulic, które składają się z szeregu następujących po sobie wnętrz urbanistycznych; takim jest również Krakowskie Przedmieście w Lublinie (Wejchert K. 1984, s. 170). W układzie sieciowym trudno odnaleźć jednoznaczne analogie do układów wnętrz przestrzeni miejskich tu analogię można odnaleźć w połączonych dziedzińcach i podwórkach. Hierarchiczny układ w przestrzeni miejskiej jest analogiczny sytuacją, może być w historycznych strukturach szeregów rynków, lub placów a łączył ja główny rynek lub sieć ulic. Plac, rynek, agora to najsilniejsza konotacja z układem jedno przestrzennym. Do takich wnętrz należy również dach katedry w Mediolanie, który został zaaranżowany na ekspozycję nowoczesnych rzeźb. To niezwykłe zestawienie gotyckiej katedry i współczesnych obiektów, a tłem do tego dialogu był pejzaż miasta (ryc. 4, 9). 
Tab. 1 Zestawienie analogii pomiędzy przestrzeniami ekspozycyjnymi i strukturami urbanistycznymi. Źródło: autorka.

\begin{tabular}{|l|l|l|}
\hline Typ ekspozycji & Przestrzeń w muzeach i galeriach & Przestrzenie miejskie \\
\hline obwodowy & $\begin{array}{l}\text { układ sal ekspozycyjnych wokoło dziedzińca, } \\
\text { pionu komunikacyjnego }\end{array}$ & $\begin{array}{l}\text { rynek, plac z centralnie zlokalizowanym } \\
\text { obiektem architektonicznym. }\end{array}$ \\
\hline liniowy & korytarzowy lub amfiladowy układ ekspozycji & ulice, aleje, wydłużone place \\
\hline hierarchiczny & $\begin{array}{l}\text { jedna główna sala z przyległymi salami eks- } \\
\text { pozycyjnymi }\end{array}$ & $\begin{array}{l}\text { główna przestrzeń sprzężona } \\
\text { z innymi wnętrzami urbanistycznymi }\end{array}$ \\
\hline sieciowy & $\begin{array}{l}\text { układ równorzędnych przestrzeni ekspozycyj- } \\
\text { nych, widzowie sami wybierają }\end{array}$ & $\begin{array}{l}\text { układ dostępnych wewnętrznych dziedziń- } \\
\text { ców }\end{array}$ \\
\hline otwarty plan /halowy & jednoprzestrzenne hala ekspozycji & otwarty plac rynek \\
\hline
\end{tabular}

\subsection{Strategie wystawiennicze w kompozycji miejskich ekspozycji}

W projektowaniu przestrzeni wystawy można wyróżnić trzy podejścia - strategie:

- myślenie detalem - skupienie się na eksponacie i jego najbliższym otoczeniu

- narracja - gdzie najistotniejsza staje się treść, opowiadanie o

- przestrzeń - istota jest w komponowaniu i budowaniu relacji pomiędzy eksponatem a miejscem, pomiędzy kolejnymi wystawionymi obiektami.

Te samo podejścia można odnaleźć w koncepcjach prezentacji w przestrzeniach miejskich. Wystawy informacyjne, okolicznościowe to jeden z przykładów pierwszej strategii. Jakość i forma koncepcji prezentacji decyduje o odbiorze. Cel sposobu wystawienia skupiony jest na tym, co jest prezentowane, a nie gdzie to jest: miejskim placu, rynku, ulicy. Odpowiednikiem takiego działania w mieście jest lokalizacja dzieł sztuki w odniesieniu do najbliższego planu ekspozycji bez szerszych odniesień oraz kiedy decyzje skupione są na dziele i autorze.

W narracji dominuje treść, jej przekazanie jest nadrzędnym celem. Ranga i istota opowiadania wpływa na lokalizację, skalę, odniesienia lub jej brak. Pomnik Karola Marcinkowskiego w Poznaniu (ryc. 11) jest współczesnym przykładem takich decyzji (Poznań, 2018).

Trzecia koncepcja pozwala na poszukiwanie harmonii dzieł sztuki i podnoszenia jakości wspomnianych wcześniej. Wraz z poszerzeniem się punktów odniesienia pojawia się wiele istotnych czynników. Eksponowanie wymaga doboru odpowiednich środków i sposobów prezentacji. W neutralnych przestrzeniach muzeów i galerii rzeźby eksponowane są według różnych kryteriów doboru np. twórcy, epoki, kierunku artystycznego, kontekstu historycznego, chronologii zakupu, własności kolekcjonerskiej, kontekstu kulturowego czy też gabarytów i wielkości zbiorów. Wszystkie dobierane kryteria i działania mają na celu podkreślenie walorów artystycznych obiektu, ekspresję formy i czytelności dobranej kolekcji. Zwiedzający obcuje „sam na sam” z dziełem sztuki w wykreowanym dla niego otoczeniu, które w jak najmniejszy sposób ma ingerować w eksponat. W wypreparowanej przestrzeni można panować nie tylko nad kompozycją przestrzenną, barwą, oświetleniem i natężaniem zwiedzających, ale również nad dźwiękiem czy też zapachem i niezmiennością w czasie. Przestrzeń miasta nie daje tego komfortu, jest ograniczona możliwość panowania nad dynamiką zmian otoczenia. Możemy poszukiwać konkretnego miejsca dla danego obiektu lub poszukiwać odpowiedniej obiektu dla wybranego miejsca. Pomimo wyboru otocznia lub formy rzeźbiarskiej, pozostaje silny aspekt zmienności. W przestrzeni urbanistycznej trudno znaleźć jednorodne tła ekspozycji; każda elewacja, każde ujęcie może być różne od sąsiadującego, jak również zmienne w czasie np. ściana zieleni zmienna wraz porami roku.

Poza zmiennością tła wagi nabiera oddalenie od tła i relacja skali. Dystans pozwala na wzmacnianie lub osłabianie relacji z tłem, decydowania, na jakim tle będzie obiekt eksponowany. Generalizując można wyróżnić trzy podstawowe przypadki: 
- pomiędzy obiektem a tłem jest dystans, który pozwala nawiązać im relacje między rytmami, formą, skalą, jednocześnie każdy z nich wyraźnie jest osobnym obiektem, ma swoją przestrzeń percepcji jednym najlepszych przykładów jest lokalizacja pomnika Marka Aureliusza na Kapitolu.

- oderwanie od tła charakterystyczne dla układów krajobrazowych, obiektów na placach, osiach dróg. Odległość od ściany elementu zatrzymania jest dużo większa niż w pierwszym przypadku. W większości ujęć ekspozycyjnych obiekt prezentowany jest na tle nieba, bądź posadzki lub zdecydowanie oddalonej pierzei, obiekcie architektonicznym.

- relacja wtopienia, zaplanowanego silnego dialogu z tłem. Przypadek znany dla form rzeźbiarskich, które powstały jako integralna część dzieła architektonicznego lub kompozycji. Współczesne realizacje sięgają po ten rodzaj prezentacji, jak wspomniana wcześniej kompozycja rzeźb „Nierozpoznani” również wielki niebieski niedźwiedź opierający się o szklaną elewację budynku rzeźba „I see what you meen” dzieło Lawrence Argente Denver USA (Pluta K., 2012, s. 224) to przykłady takich działań.

\subsection{Wystawa Igora Mitoraja}

W 2003 roku w trzech miastach Polski zaprezentowano ekspozycję rzeźb Igora Mitoraja. Za przestrzeń ekspozycji dla największych obiektów posłużyły wnętrza Starego Rynku w Poznaniu, Rynku Głównego w Krakowie oraz zewnętrzny i wewnętrzny Plac Zamku Królewskiego w Warszawie.

Poznań było pierwszą odsłoną tego przedsięwzięcie, unikatowego pod względem skali. Pod część ekspozycji na placu zostały wykonane specjale podstawy cementowe w celu stabilnego ich osadzenia. Ekspozycja na Starym Rynku została zaaranżowana na zachodniej i południowej pierzei. Rzeźby były zaprezentowane na brukowej posadzce. Pierzeja zachodnia to była liniowa kompozycja kilku rzeźb skierowanych ku centralnej części placu, kompozycyjnie osadzonych w relacji z tłem kamienic. Druga część prezentacji to oddalone od siebie rzeźby zdecydowanie różniące się od siebie wielkością i formą, a tak i tu komponowane w relacji ze ścianami urbanistycznymi wnętrza. Pod względem decyzji wystawienniczych bardzo spójnie i konsekwentnie poprowa,2,dzone założenie. Pozostała część ekspozycji mieściła się w Muzeum Narodowym w Poznaniu (ryc.1,2,5,12).

Głównym Rynku w Krakowie w 2004 roku zostało zaprezentowanych 14 prac artysty (Badach,2004, s. 71). Aranżacja ekspozycji to efekt poszukiwania miejsca dla każdego z obiektów. Sala wnętrza i wielkość kolekcji pozwoliła zbudować szereg unikalnych relacji pomiędzy rzeźbami a przestrzenią. Prezentacja została zaaranżowana na dużym obszarze rynku, eksponaty ustawione zostały na ważnych osiach, zakomponowana została grupa w północno-zachodniej części w centralnej części posadzki wnętrza w oderwaniu od ścian wnętrza. Kolejne rzeźby znalazły swoje miejsce w relacji z tłem np. Kościoła Świętego Wojciecha. Krakowska prezentacja to paletę urbanistycznych i wystawienniczych rozwiązań. Ekspozycja plenerowa uzupełniała ekspozycję w kamienicy „Pod Krukiem”.

Warszawska ekspozycja była największa i najbardziej rozproszoną. Ekspozycja w przestrzeni miasta miała miejsce na Placu Zamkowym. Tu w odróżnieniu od poprzednich lokalizacji część ekspozycji została zlokalizowana na miękkim podłożu skweru, ustawione liniowo budowały artykulację. Ciekawe jest to, że jak w poznańskim i krakowskim przypadku aranżacja rzeźb były w kierunku przestrzeni; to tu obiekty kompozycyjnie są zwrócone do siebie. Znakomicie prezentowała się głowa na tle elewacji Zamku Królewskiego, to wymagająca ekspozycyjna przestrzeń w obniżeniu (Badach, 2004, s.72). Plac zewnętrzny i jego relacja $z$ wewnętrznym to analogia do układów hierarchicznych, wewnętrzna ekspozycja to kompozycja z silną relacją z tłem (ryc. 13-15).

Przestrzenie miast stały się niezwykłym miejscem ekspozycji prac jednego artysty $w$ tym samym momencie. Trzy przestrzenie miejskie były laboratorium wystawienniczym, w każdym posłużono się indywidualnym podejściem do przestrzeni. To wrażliwe na przestrzeń podejście pozwoliło osiągnąć efekt, że dzieła Mitoraja były głównym aktorem w dialogu z pięknym historycznym miejscem.

\section{WNIOSKI}

Obiekty wystawiennicze są nieporównywalne w skali do galerii, jaką jest miasto; zaprezentowane zestawienie ukazuje analogie kodów w kształtowaniu struktur ekspozycyjnych, poruszanie się 
w oswojonych strukturach i działa to w dwie strony. Współczesną inspiracją miastem dla budowanie struktury muzeum jest realizacja Muzeum Louvre w Abu Dhabi projektu Jeana Nouvela otwarty w roku 2017 (Louvre Abu Dhabi, 2018). W artykule przedstawiono badania dotyczące zagadnień obiektów sztuki w przestrzeni publicznej z punktu widzenia doświadczeń ekspozycyjnych. Zagadnienie jest poruszane głównie jako element kompozycji miasta w skali urbanistycznej lub symbolicznej. Wystawiennicze aspekty pozwalają rozpatrywać je z punktu widzenia bardziej kameralnej skali. Wskazane zostały analogie pomiędzy konstrukcją wystaw w przestrzeniach ekspozycyjnych a strukturami miasta. Pozwala to rozpatrywać miasto jako świadomie zaprojektowaną galerię sztuki, którą można kontemplować, przeżywać pozwala tworzyć atrakcyjną rozpoznawalna przestrzeń. Można posłużyć się wieloma zabiegami dla osiągnięcia celu, jakim jest poszukiwanie harmonii - piękna pomiędzy obiektem eksponowanym - tłem - przestrzenią. Nie wszystkie aspekty zostały poruszone, a zagadnienie wymaga dalszych badań.

\section{BIBLIOGRAPHY}

Badach A., 2004. Igor Mitoraj- Powrót do ojczyzny. Muzealnictwo no 45, 2018, p. 71-79.

Borusiewicz M., 2012. Nauka czy rozrywka. Nowa muzeologia w europejskich definicjach muzealnych. Muzeologia Vol. 4, Universitas, Kraków. ISBN 97883-2424-1751-9.

Bardzińska-Bonenberg, T., Sobczyńska, K. 2018. Greenery, a historical townscape marker and stimulator. Poznan as a case study. DOI: 10.21005/pif.2018.33.A-01. Space\&form / Przestrzeń i forma no 33, 2018, pp. 942.

CAMPO DE' FIORI www.romasegreta.it/parione/campo-de-fiori.html dostęp/access 2018-12-10.

Gehl J., 2014. Miasta dla Ludzi, RAM, Kraków. ISBN 978-83-928610-0-3.

Hoffman H.W. 2016. Construction and Design Manual. Museum Buildings, DOM Publisher, Berlin, DETAIL, Monachium. ISBN 978-3-86922-217-2.

Januchta-Szostak A., 2007. Obiekty rzeźbiarskie jako element tożsamości krajobrazu Poznania. Zeszyty Naukowe Politechniki Poznańskiej. Architektura i Urbanistyka no12, 2007 pp. 53-68.

Loos A., 2013. Ornamenty i zdobienia. Eseje wybrane”, BWA Tarnów, Centrum Architektury. ISBN 978-83935538-9-1, ISBN 978-83-934574-7-2.

Louvre Abu Dhabi www.jeannouvel.com/en/projects/louvre-abou-dhabi-3/, dostęp/access 2018-12-15.

MITORAJ - wystawa jego rzeźb na Rynku i w Muzeum Narodowym w Poznaniu www.rosikonpress.com/wydarzenie_1/MITORAJ_wystawa_jego_rzezb_na_Rynku_i_w_Muzeum.html, dostęp/access 2018-12-15 .

Pluta K., 2012. Przestrzenie publiczne miast europejskich. Projektowanie urbanistyczne", Oficyna Wydawnicza Politechniki Warszawskiej, Warsaw. ISBN 978-83-7814-044-3

Poznań, Odsłonięcie pomnika Karola Marcinkowskiego www.poznan.pl/mim/info/news/odsloniecie-pomnikakarola-marcinkowskiego,4903.html, dostęp/access 2018-12-15.

Uffelen Ch., 2012. 500 x Art. in Public. Braun, Berlin. ISBN 978-3-03768-098-8

Watkin D. 1996. Historia Architektury wspótczesnej. Arkady, Warsaw. ISBN 83-213-4178-0

Wejchert K. 1984. Elementy kompozycji urbanistyczne. Arkady, Warsaw. ISBN 83-213-4178-0

Żórawski J.1962. O budowie formy architektonicznej. Arkady, Warsaw.

\section{AUTHOR'S NOTE}

Lecturer at the Faculty of Architecture of the Poznan University of Technology. She conducts lectures and classes on exhibition studies and architectural and industrial design classes at the Institute of Architecture and Spatial Planning. Her scientific interests Focus on exhibition architecture, and in particular on the relations between the displayed objects and their surroundings. The academic work of the author is supported by her long-term experience in designing trade fair exhibitions. 


\section{O AUTORZE}

Adiunkt na Wydziale Architektury Politechniki Poznańskiej w Instytucie Architektury i Planowania Przestrzennego; prowadzi wykłady i ćwiczenia z zakresu wystawiennictwa oraz zajęcia projektowe $z$ architektury oraz projektowania przemysłowego. Zainteresowania naukowe koncentrują się na architekturze wystawienniczej, a w szczególności na relacjach pomiędzy wystawianym obiektem a jego otoczeniem. Praca naukowa jest poparta długoletnim doświadczeniem projektowym w zakresie wystawiennictwa targowego.

Contact | Kontakt: magdalena.gyurkovich@put.poznan.pl 